
ANDRZEJ BORZĘCKI²

\title{
The attitude of students of Academy of Physical Education to alcohol consumption
}

\begin{abstract}
Introduction. Alcohol is found to contribute to everyday life of young people. Frequent heavy drinking, violent behavior under influence of alcohol are typical for youths. Unreasonable over-consumption of alcohol might have direct impact on their health in adulthood, as initially controlled amount of alcohol drinking can gradually lead to abuse and further, to alcohol addiction.

Aim. The aim of the study was to evaluate the prevalence of alcohol consumption and to notify knowledge of the harmful effects of alcohol on human body.

Material and methods. The study was conducted among 276 fifth-year students (including 206 men and 70 women). Students filled out an anonymous questionnaire containing AUDIT test.

Results. Risky model of alcohol consumption was observed among $75.72 \%$ of students whereas alcohol-addicted group accounted for $1.81 \%$. The remaining group of students $(22.47 \%)$ was reported as harmful alcohol consumption model. Beer was the most often consumed alcohol.

Conclusions. Abstinence from drinking alcohol is a rarely observed phenomenon among students of the Academy of Physical Education. Future PE teachers should be urgently motivated to educate and to encourage youths about healthy life style.
\end{abstract}

Keywords: students, alcohol, AUDIT test.

DOI: $10.1515 /$ pjph-2015-0010

\section{INTRODUCTION}

In everyday life students face variety of harmful elements, one of which is the consumption of alcohol. Following standards of older colleagues and patterns from the family home is a common reason for alcohol consumption. Students often treat alcohol consumption as a form of entertainment and pleasure. An excessive consumption of alcohol by adolescents is one of the negative results of current civilization development. Alcohol intake at young age can cause long-term biological changes in the body, which influence further human development. The earlier young people reach alcohol and the more they drink, the more they are exposed to alcohol addiction. Alcohol interferes with the ability to study and often even can lead to learning difficulties. In addition, adolescents have less tolerance to alcohol than adults do. This means that even small alcohol intake may cause uncontrolled behavioral changes [1]. Alcohol consumption by students has been within the higher level of interest at the recent times. Current scientific reports indicate high intensity of alcohol intake by students [2]. Phenomenon of heavy drinking in the early adulthood is so widespread that certain percentage of society does not notice these disturbing behaviors. However, the issue of possible abuse of alcohol by students inclines preventive action. Therefore, it is appropriate to conduct regular studies on the prevalence of alcohol intake among students. Students of Physical Education should be particularly aware of the harmful risk associated with alcohol consumption because as the forthcoming teachers of physical education they will be responsible for healthy lifestyle of youths.

\section{AIM}

The aim of the study was to assess the prevalence of alcohol consumption and to evaluate opinion about the harmful effects of alcohol on the human body.

\section{MATERIAL AND METHODS}

The study was conducted among 276 first-year students of Physical Education (including 206 men and 70 women). Each of the respondents filled up anonymous questionnaire regarding alcohol consumption including AUDIT test. AUDIT test was developed by WHO to determine if a person's alcohol consumption may be harmful, risky or addictive.

\footnotetext{
${ }^{1}$ Department of Health Promotion, Faculty of Physical Education and Sport in Biała Podlaska, Józef Piłsudski University of Physical Education in Warsaw, Poland

${ }^{2}$ Chair and Department of Hygiene, Medical University in Lublin, Poland

${ }^{3}$ Medical University of Lublin, II Faculty of Medicine with the English Division, Department of Public Health, Poland
} 
The test qualified students into three groups. The group A indicates hazardous alcohol consumption and includes respondents who in the question 1-3 obtained the following number of points: women -4 and more points, men -5 and more points. The group $\mathrm{B}$ indicates alcohol addiction and includes those who obtained in the questions 4-6 the following numbers of points: women -4 points and above, men5 points. The group $\mathrm{C}$ recognizes harmful alcohol consumption and included respondents who scored in the questions number 7-10 above 4 points, regardless the gender. Each time the questionnaire was carried out in the presence of one of the authors of the study. Statistical analysis was made based on STATISTICA 7.1 program assuming the level of significance $\mathrm{p}<0.05$.

\section{RESULTS}

Among the respondents, non-drinkers account for $3.26 \%$. The result of $2.53 \%$ includes students who admitted no alcohol consumption over the last month. Other students (94.21\%) declared alcohol consumption over the month preceding the survey. Among students who drink alcohol, 17.02\% admitted to alcohol consumption during the week whereas $82.98 \%$ declared alcohol intake only during weekend. Analysis of points scored in AUDIT test recognized $75.72 \%$ of students in the group of hazardous alcohol consumption including $34.9 \%$ of women and $65.1 \%$ of men $(\mathrm{p}<0.0001)$. Addiction to alcohol was confirmed by $1.81 \%$ of students and they were only men $(p<0.001)$. Other students $(22.47 \%)$ represented harmful alcohol consumption including $90.32 \%$ men and $9.68 \%$ women $(p<0.0001)$. Consumption of alcohol at the early age which is below 16 years of age was declared by $35.14 \%$ of students including $30.92 \%$ women and $69.08 \%$ men respectively $(p<0.002)$. All of the respondents admitted that beer was the most frequently consumed alcohol. As the negative consequence of alcohol consumption students most frequently mentioned the following: driving under the influence of alcohol (2.74\%); risky or unwanted sexual behavior $(5.79 \%)$; participation in fights $(43.47 \%)$, vandalism $(3.62 \%)$. Other students $(25.38 \%)$ pointed to amnesia. Significant group of students $(81.8 \%)$ did not disapprove excessive alcohol consumption among their peers.

\section{DISCUSSION}

Increasing numbers of young people turn to alcohol. With every year, the age at which alcohol drinking initiation is reported is systematically decreasing, whereas drinking intensity and number of people who drink, dangerously increases. It seems that alcohol consumption and excessive alcohol drinking observed among young people is a growing problem of the modern civilization. After analyzing the results of the study, early initiation of alcohol intake among the surveyed group of respondents is noticed (35.14\%). The obtained results are comparable with results shown by Mierzecki et al. Research, which they conducted among firstyear students of Pomeranian Medical University in Szczecin and Ernst-Moritz-Arndt University in Greifswald showed consumption of alcohol at early age among $32 \%$ of students in Szczecin and 53\% of students in Greifswald, respectively.
Respondents in the above-mentioned research admitted to drinking alcohol as entertainment during leisure time and declared beer as the most frequently chosen alcohol similarly to students of Physical Education [3]. Also Tishcheenko et al. noticed early initiation of alcohol drinking among students of Grodno. The average age of early alcohol consumption accounted for $14.7+/-0.46$ years and more than half of the respondents drunk alcohol in the last 30 days preceding the survey [4]. Alcohol drinking is the major factor leading to violence, increased traumatism and incidence of hazardous sexual behavior [5-7]. Own study showed a tendency to aggressive outbreaks after alcohol consumption noticed among the surveyed students $(43.47 \%)$ and drinking and driving phenomena at least once in their lives was reported by $21.74 \%$. Klimberg et al. [8] analyzed a population of students from various courses at Karol Marcinkowski Medical University in Poznań during academic year 2004/2005. A large number of examined students admitted to commitment of unwanted acts under influence of alcohol inebriation and the most common was cigarette smoking (30.2\%) or undesired sexual behavior $(6.2 \%)$. Alcohol intoxication including hangover $(54.4 \%)$, loss of consciousness $(35.6 \%)$ and amnesia $(17.1 \%)$ was also frequently observed. In the study of Klimberg et al. [9] $85.1 \%$ of medical students admitted to alcohol consumption in the past 30 days prior to the study, including $89.3 \%$ of men and $83.7 \%$ of women. Beer was the most frequently chosen alcohol (80.3\%). Also in a study conducted by Kułak et al. students declared most often drinking beer $(59.8 \%)$ and over the past week alcohol was consumed by $60 \%$ of respondents. It is alarming to notice that almost $74.3 \%$ of respondents did not mind excessive alcohol consumption among their peers [10]. The analysis of the obtained results prove that more than $3 / 4$ of the surveyed students did not disapprove their colleagues for intensive alcohol drinking. Research of Borkowski et al. showed that about $80 \%$ of respondents (out of 1320) drank alcohol during the 30 days preceding the survey. All of those respondents declared drinking beer at that time, 50\% declared drinking vodka and about $1 / 3$ - wine. More than half of the respondents admitted to getting drunk at least once during the 30 days preceding the research and experienced problems related to alcohol drinking in the past 12 months. The following most commonly occurring problems were noticed in the study of Borkowski et al.: arguments and quarrel (37\%), fights $(22 \%)$, problems with parents $(26 \%)$ damage to clothes or items (20\%) [11]. Analysis of self-study showed that $75.72 \%$ of students represented hazardous model of alcohol drinking. The second group is represented by students who drink in harmful way $(22.47 \%)$. In addition, $1.81 \%$ of students were identified within alcohol-addicted group. The obtained results differ from those observed by Gesternkorn et al. In the aforementioned studies, which were conducted only among six-year students of medicine, $46.5 \%$ of respondents were identified with hazardous drinking and nearly three time more often men than women. In the described studies, the percentage of people who were recognized with alcohol problems resulting from AUDIT screening test accounted for $4.3 \%$ [12]. Based on the conducted study, alcohol dependence as defined in ICD-10 cannot be clearly determined; however, harmful manner of alcohol drinking among 
respondents is a fact. The obtained results remain alarming as they indicate that in the period of study almost entire group of youth drank alcohol in the month preceding the survey.

\section{CONCLUSION}

1. Alcohol abstinence is rarely observed among the students of Academy of Physical Education

2. Unfortunately, high awareness of harmful effects of alcohol does not correspond to the appropriate attitude towards alcohol consumption

3. Educational activities, which aim at motivating future teachers to promote healthy lifestyle among youths, need to be undertaken.

\section{REFERENCES}

1. Grzybowski A. Alkoholizm - stale aktualny problem zdrowotny społeczeństwa Polskiego. Aktywność samorządu w zakresie profilaktyki alkoholowej. Now Lek. 2005:74(2);44-50.

2. Quigley L, Marlatt G. Picie alkoholu wśród ludzi dorosłych w młodym wieku. Alkohol, a zdrowie. 2000;25:112-25.

3. Mierzecki A, Wisniewska M, Erber H, et al. Porównanie modelu picia alkoholu przyjętego przez studentów I roku medycyny w Szczecinie i Greifswaldzie. Zdr Publ. 2006;116(4):568-71.

4. Tishchenko E, Marcinkowski JT, Surmach M. Features of the alcohol initiation and the subsequent attitude to it of the future doctors. Hygeia Public Health. 2010;45(1):62-6.

5. Gullette DL, Lyons MA. Sensation seeking, self-esteem, and unprotected sex in college students. J Assoc Nurses AIDS Care. 2006;17:23-31.

6. Landry DJ, Darroch JE, Singh S, et al. Factors associated with the content of sex education in U.S. public secondary schools. Perspect Sex Reprod Heath. 2003;35:261-9.

7. Woynarowska B, Mazur J. Zachowania zdrowotne młodzieży szkolnej w Polsce: wyniki badań HBSC 2002. Zdr Pub. 2004;114:159-67.

8. Klimberg A, Marcinkowski JT, Przybylski J. Konsumpcja alkoholu i innych środków psychoaktywnych wśród studentów poszczególnych kierunków uniwersyteckich studiów medycznych. Cześć III. Przyczyny i okoliczności konsumpcji napojów alkoholowych oraz ich następstwa. Probl Hig Epidemiol. 2009;90:47-54.

9. Klimberg A, Marcinkowski JT, Przybylski J. Konsumpcja alkoholu i innych środków psychoaktywnych wśród studentów poszczególnych kierunków uniwersyteckich studiów medycznych. Cześć II. Obecna konsumpcja napojów alkoholowych. Probl Hig Epidemiol. 2008;89:526-30

10. Kułak A, Shpakov A, Kułak P. Wstępna analiza problemu nikotynizmu, alkoholizmu i narkomanii w populacji studentów Preliminary analysis of the problem of nicotine, alcohol and drug addictions in the student population. Probl Hig Epidemiol. 2011;92(1):137-45

11. Borkowski K. Fazy używania nielegalnych substancji psychoaktywnych a picie alkoholu wśród młodzieży i młodych dorosłych. Alkohol Narkom. 2008;21(4):341-62.

12. Gerstenkorn A, Suwała M. Problem medyczno-społeczny spożywania alkoholu w grupie przyszłych lekarzy. Wiad Lek. 2003;LVI:9-10,402-6.

\section{Corresponding author}

Prof. dr hab. $\mathrm{n}$ med. Andrzej Borzęcki

Chair and Department of Hygiene, Medical University in Lublin

11 Radziwiłłowska Str., 20-080 Lublin

tel.: 81 528-84-02 